\title{
Vegetative and Reproductive Development of Costa Rican WeEdy RICE COMPARED WITH COMMercial RICE (Oryza sativa) ${ }^{1}$
}

\author{
Comparação do Desenvolvimento Vegetativo e Reprodutivo do Arroz-Vermelho e Variedades \\ Comerciais de Arroz (Oryza sativa) da Costa Rica
}

\begin{abstract}
SÁNCHEZ-OLGUÍN, E. ${ }^{2}$, ARRIETA-ESPINOZA, G. ${ }^{3}$ and ESPINOZA ESQUIVEL, A.M. ${ }^{4}$
ABSTRACT - The variability in the chronology of the vegetative and reproductive development of weedy rice complex has been little studied. However, a field trial was established to study the timing of growth stages of sixteen weedy rice morphotypes and five rice varieties of Costa Rica. Weedy rice presented a wide range of variation for all descriptors among and within morphotypes. Weedy rice was taller than the rice varieties during vegetative phase and showed a growth increase of 14-23 cm every two weeks. Six morphotypes emerged earlier than commercial rice varieties, but no differences where found between samples for the time required for starting tillering. Early emergence of weedy rice morphotypes was not associated with early flowering, thus no correlation was detected between the vegetative and reproductive phases. All weedy rice morphotypes reached anthesis and maturity earlier than the rice varieties. Nevertheless, varieties Setesa-9 and CR-5272 overlapped anthesis with eleven morphotypes and variety CR-4338 overlapped flowering with eight weedy rice morphotypes. In contrast, none of the morphotypes overlapped anthesis with varieties CR-1821 and CR-1113. The results obtained showed the competitive capacity of weedy rice and provided valuable information about flowering overlap between weedy rice morphotypes and rice varieties which will be useful in the design of gene flow studies among them.
\end{abstract}

Keywords: anthesis overlapping; growth stages; red rice; rice varieties.

RESUMO - O desenvolvimento vegetativo e reprodutivo das diferentes variantes morfológicas do arroz-vermelho tem sido pouco estudado. Um ensaio de campo com dezesseis morfotipos de arroz-vermelho e cinco variedades comerciais de arroz da Costa Rica foi estabelecido com o fim de estudar crescimento dessa planta daninha. Nos resultados, observou-se que o arroz-vermelho mostrou amplo intervalo de variação durante seu ciclo de vida. Em geral, essas plantas foram mais altas que as variedades durante a fase vegetativa e apresentaram incrementos de altura entre 14 e $23 \mathrm{~cm}$ quinzenal. Seis dos morfotipos avaliados emergiram antes que as variedades comerciais de arroz, porém nao foram detectadas diferenças entre as amostras quanto ao momento em que iniciaram o perfilhamento. Os morfotipos que emergiram primeiro não foram os mesmos que alcançaram a floração primeiro; por esse motivo, não se pode estabelecer correlação entre a fase vegetativa e a reprodutiva. Todos os tipos de arroz-vermelho floresceram $e$ amadureceram sua semente antes das cinco variedades comerciais de arroz. Entretanto, as variedades Setesa-9 y CR 5272 sobreporam em floração com onze morfotipos. Em contraste, as variedades CR 1821 e CR 1113 não sobreporam em floração com nenhum dos morfotipos avaliados. Os dados obtidos mostram a capacidade competitiva do arroz-vermelho e, ao mesmo tempo, dão informação valiosa sobre as sobreposições de floração entre morfotipos de arrozvermelho e as variedades comerciais de arroz. Essa informação será útil para o desenho de estudos do fluxo gênico entre a planta daninha e o cultivo.

Palavras-chave: sobreposição de floração, fases de desenvolvimento, arroz-daninho, variedades de arroz.

Recebido para publicação em 16.3.2006 e na forma revisada em 27.2.2007.

Agro-Eng. M.S. Researcher at Centro de Investigaciones en Biología Celular y Molecular, Universidad de Costa Rica. Postal Box 2060 San José, Costa Rica, <elena.sanchez.o@gmail.com>; ${ }^{3}$ Agro-Eng M.S. Researcher at Centro de Investigaciones en Biología Celular y Molecular. Universidad de Costa Rica. Postal Box 2060 San José, Costa Rica, <griselda.arrieta@gmail.com>; ${ }^{4}$ Agro-Eng. PhD Researcher at Centro de Investigaciones en Biología Celular y Molecular and Profesor at Escuela de Agronomia Facultad de Ciencias Agroalimentarias Universidad de Costa Rica. Postal Box 2060 San José, Costa Rica 〈amespino@ racsa.co.cr〉. 


\section{INTRODUCTION}

Weedy rice (Oryza spp.), also known as red rice, is a highly polymorphic group of plants of the rice agro-ecosystem that competes with cultivated rice varieties for space and resources. In tropical America, weedy rice is the most economically important weed in rice fields (Agüero, 1996; Madsen et al., 2002), especially in areas with continuous direct sowing (Montealegre \& Vargas, 1992; Ortiz et al., 1999; Gealy et al., 2000; Agostinetto et al., 2001). Weed control represents a significant issue in the Costa Rican rice production since $20 \%$ of the cost is devoted to this practice (Madsen et al., 2002). In the last eight years, weedy rice has colonized a considerable proportion of the commercial and seed production areas of the country. From 1997 to 2003 , from $7.4 \%$ to $24 \%$ of seed production areas were rejected due to weedy rice infestations (Oficina Nacional de Semillas 1998-2005). As a consequence, increasing abandonment of infested rice fields has occurred.

Controlling weedy rice is difficult due to its physiological and morphological similarity to commercial rice varieties, easy seed shattering and seed dormancy. Therefore, manual elimination of panicles, cultural practices, and herbicide application are carried out to control the weed at specific times during the rice production cycle (Hernández et al., 1979; Esqueda, 2000; Ferrero, 2003).

Since weedy rice control practices are expensive and inefficient, a comprehensive study on weedy rice diversity and biology is necessary to develop and implement better control strategies. In Costa Rica, the morphometric relationships of the weedy rice complex with commercial rice varieties, land races and wild Oryza species were established by comparing 27 morphological traits (ArrietaEspinoza et al., 2005). This study allowed the identification of 21 distinct weedy rice morphotypes and revealed that the weedy rice complex was highly diverse. In addition to morphology, the study of plant life cycle represents an important complement to quantify the diversity of the weedy rice complex.

In addition, several weedy rice studies have focused on aspects such as seed dormancy
(Cohn et al., 1987; Cohn et al., 1989; Delatorre, 1999), emergence (Gealy et al., 2000), flowering time and interference with the cultivated varieties (Kwon et al., 1991; Pantone \& Baker, 1991; Ortiz et al., 1999; Estorninos et al., 2002; Fonseca et al., 2004). However, the chronology of the vegetative and reproductive life cycle of weedy rice has been less studied.

The purpose of this research was to evaluate the vegetative and reproductive development of weedy rice morphotypes compared to commercial rice varieties to determine the variability of weedy rice and associate it to red rice weediness.

\section{MATERIALS AND METHODS}

\section{Plant materials}

Accessions from sixteen weedy rice morphotypes were collected in tree paddies $\left(09^{\circ} 31^{\prime} \mathrm{N}, 84^{\circ} 22^{\prime} \mathrm{W}\right.$; $09^{\circ} 31^{\prime} \mathrm{N}, 84^{\circ} 17^{\prime} \mathrm{W}$; $09^{\circ} 33^{\prime} \mathrm{N}$, $\left.84^{\circ} 14^{\prime} \mathrm{W}\right)$ of La Ligia rice farm located at Parrita in Costa Rica Pacific slope $(10 \mathrm{~m}$ above sea level). These accessions were classified into weedy rice morphotypes using the seed code described by Arrieta-Espinoza et al. (2005) that considered three seed traits: awn presence, anthocyanin in the apiculus and lemmapalea color (Table 1). Weedy rice morphotype accessions were stored at the seed bank at the Centro de Investigaciones en Biología Celular y Molecular (CIBCM-UCR). In addition, five commercial rice varieties CR-5272, CR-4338, CR-1821, CR-1113 and Setesa-9 were included in the study, using genetic seeds provided by the Centro de Investigaciones en Granos y Semillas (CIGRAS-UCR).

\section{Evaluation of growth under field conditions}

A field trial was planted in Tejar of Alajuela $\left(10^{\circ} 00^{\prime} 06.3^{\prime \prime} \mathrm{N}, 084^{\circ} 12^{\prime} 49.0^{\prime \prime} \mathrm{W}\right)$ located $932 \mathrm{~m}$ above sea level, in the Central Valley. Although Alajuela is not a rice growing area, it was selected for the location of the trial because of its proximity to CIBCM to permit the daily field evaluation required for this study. Experimental plots consisted of $5 \mathrm{~m}^{2}$ for each of the weedy rice morphotypes and of $2.5 \mathrm{~m}^{2}$ for the commercial varieties, with a $50 \mathrm{~cm}$ space between the plots and a sowing distance 
of $20 \times 20 \mathrm{~cm}$. For weedy rice, five different accessions per morphotype were planted in each plot and eleven siblings (seeds from the same accession) were sown by row. Two replicates were used by plot. Mineral fertilizer was applied as five grams per row of 10-30-10 (N-P-K) applied at sowing and $2 \mathrm{~kg} \mathrm{ha}^{-1}$ urea at 30 DAS. In addition, weekly applications of alternating magnesium sulfate and potassium sulfate $\left(2 \mathrm{~kg} \mathrm{ha}^{-1}\right)$ were performed to prevent magnesium and potassium deficiencies.

\section{Morphometric, vegetative and reproductive descriptors}

Three morphometric descriptors (tillering ability, number of leaves and plant height) were evaluated every two weeks during the vegetative cycle. In addition, three vegetative and five reproductive descriptors for $O$. sativa, defined according to the Standard Evaluation System for Rice (International Rice Research Institute, 2002), were also evaluated for each

Table 1 - Description of Costa Rican weedy rice morphotypes and rice varieties. Weedy rice morphotype code based on seed morphology; awn, apiculus and lema-palea color according to Arrieta-Espinoza et al. (2005). Numbers in parenthesis correspond to IRRI $(1980,1996)$ morphological rice descriptors. Average values (means \pm SD) of height and tiller number of accessions per morphotype. Data from mature plants collected in Parrita rice fields

\begin{tabular}{|c|c|c|c|c|c|}
\hline Weedy morphotype & Awn & $\begin{array}{l}\text { Apuculus } \\
\text { color }\end{array}$ & $\begin{array}{c}\text { Lemma and palea } \\
\text { color }\end{array}$ & $\begin{array}{l}\text { Average height } \\
(\mathrm{cm})\end{array}$ & $\begin{array}{c}\text { Average tiller } \\
\text { number }\end{array}$ \\
\hline WM-020 & Awnless (0) & Straw (2) & Straw (0) & $117.2 \pm 13.9$ & $4.2 \pm 1.9$ \\
\hline WM-021 & Awnless (0) & Straw (2) & $\begin{array}{l}\text { Gold furrows on } \\
\text { straw background (1) }\end{array}$ & $105.4 \pm 21.0$ & $5.7 \pm 3.6$ \\
\hline WM-023 & Awnless (0) & Straw (2) & $\begin{array}{l}\text { Brown furrows on } \\
\text { straw background (3) }\end{array}$ & $107.7 \pm 21.8$ & $4.1 \pm 2.8$ \\
\hline WM-024 & Awnless (0) & Straw (2) & Brown tawny (4) & $95.3 \pm 15.4$ & $4.3 \pm 2.8$ \\
\hline WM-070 & Awnless (0) & Purple (7) & Straw (0) & $119.5 \pm 17.6$ & $5.0 \pm 4.9$ \\
\hline WM-071 & Awnless (0) & Purple (7) & $\begin{array}{l}\text { Gold furrows on } \\
\text { straw background (1) }\end{array}$ & $118.2 \pm 9.4$ & $3.9 \pm 2.0$ \\
\hline WM-073 & Awnless (0) & Purple (7) & $\begin{array}{l}\text { Brown furrows on } \\
\text { straw background (3) }\end{array}$ & $118.0 \pm 9.1$ & $3.3 \pm 1.5$ \\
\hline WM-120 & Straw (1) & Straw (2) & Straw (0) & $118.5 \pm 11.3$ & $3.8 \pm 2.4$ \\
\hline WM-121 & Straw (1) & Straw (2) & $\begin{array}{l}\text { Gold furrows on } \\
\text { straw background (1) }\end{array}$ & $118.8 \pm 10.8$ & $4.1 \pm 2.3$ \\
\hline WM-122 & Straw (1) & Straw (2) & Brown (2) & $107.0 \pm 6.4$ & $10.0 \pm 9.2$ \\
\hline WM-123 & Straw (1) & Straw (2) & $\begin{array}{l}\text { Brown furrows on } \\
\text { straw background (3) }\end{array}$ & $112.0 \pm 16.0$ & $5.6 \pm 3.0$ \\
\hline WM-170 & Straw (1) & Purple (7) & Straw $(0)$ & $125.7 \pm 8.9$ & $3.8 \pm 2.2$ \\
\hline WM-171 & Straw (1) & Purple (7) & $\begin{array}{l}\text { Gold furrows on } \\
\text { straw background (1) }\end{array}$ & $132.5 \pm 7.8$ & $2.5 \pm 0.7$ \\
\hline WM-173 & Straw (1) & Purple (7) & $\begin{array}{l}\text { Brown furrows on } \\
\text { straw background (3) }\end{array}$ & $120.8 \pm 8.8$ & $4.0 \pm 2.0$ \\
\hline WM-329 & Brown (3) & Straw (2) & Black (9) & $114.6 \pm 7.6$ & $8.7 \pm 5.8$ \\
\hline WM-379 & $\operatorname{Brown}(3)$ & Purple (7) & Black (9) & $123.0 \pm 0$ & $4.0 \pm 0$ \\
\hline \multicolumn{6}{|l|}{ Rice varieties } \\
\hline CR-1113 & Straw (1) & Straw (2) & Straw (0) & $76.7 \pm 4.5$ & $3.4 \pm 2.3$ \\
\hline CR-1821 & Awnless (0) & Straw (2) & Straw (0) & $80.8 \pm 6.5$ & $6.1 \pm 2.6$ \\
\hline CR-5272 & Awnless (0) & Straw (2) & Straw (0) & $86.3 \pm 4.5$ & $13.0 \pm 1.4$ \\
\hline CR-4338 & Awnless (0) & Straw (2) & Straw (0) & $63.6 \pm 4.2$ & $7.4 \pm 3.4$ \\
\hline Setesa-9 & Awnless (0) & Purple (7) & Straw (0) & NS & NS \\
\hline
\end{tabular}


accession (Table 2). Number of days after seeding (DAS) to reach every growth stage was registered.

\section{Statistical analyses}

ANOVA multiple mean comparisons were performed for the morphometric descriptors using the Tukey's HSD test. Vegetative and reproductive descriptors were analyzed by a simple correlation analysis and multiple means comparison using ANOVA/MANOVA module of STATISTICA 5.5. Significant differences were considered when $\mathrm{p} \leq 0.05$.

\section{RESULTS AND DISCUSSION}

\section{Vegetative phase}

The results obtained in this research reflect the great variability of weedy rice morphotypes both in the morphometric and life cycle descriptors. The first descriptor evaluated was number of days after seeding (DAS) when $50 \%$ of the plants emerged. Seed germination and emergence are the first steps for plant establishment, constituting important traits for competitiveness and colonization capacity (Diarra et al., 1985; Gealy et al., 2000). Weedy and cultivated rices were similar in their percent of total emergence ranging from $63.6 \pm 23.8 \%$ to $100.0 \pm 0.0 \%$ in weedy rice and from $70.4 \pm 15.5 \%$ to $84.1 \pm 8.7 \%$ in commercial rice varieties. However, emergence of the first seedlings of weedy rice morphotypes initiated at four DAS. Thirty-eight percent of weedy rice morphotypes (WM-023, WM-123, WM-020, WM-121, WM-329 and WM-122) emerged significantly earlier $(5.8 \pm 1.8$ to $6.5 \pm 0.9$ DAS) than commercial rice varieties, what may lead to an advantage to the weedy rice during the first developmental stages. The commercial rice varieties reached $50 \%$ emergence between $9.3 \pm 1.5$ and $10.5 \pm 1.0$ DAS. A similar result was observed for $62.5 \%$ of the weedy rice morphotypes, none of which emerged later than cultivated rice (Table 3). Rapid emergence affects competitive ability; the weedy rice seedlings that emerge first, probably will benefit from the early access to environmental resources, principally light and nutrients, causing a considerable reduction on rice yield (O'Donovan et al., 1985; Agostinetto et al., 2004). In addition, these data suggest that weedy rice did not show greater secondary dormancy than cultivated rice. However, in a practical sense, this rapid emergence could also be useful for control practices, such as pre-emergence herbicide application (Diarra et al., 1985). Another control strategy to offset early weedy rice emergence is using pre-germinated commercial seeds, thereby providing competitive advantage to the crop (Agostinetto et al., 2001).

Table 2 - Morphometric, vegetative and reproductive descriptors used to evaluated weedy rice morphotypes and commercial rice varieties according to IRRI (2002). All morphometric descriptors were evaluated during the vegetative phase at 18 , $30,44,59$ and 70 days after seeding (DAS)

\begin{tabular}{|l|l|}
\hline & Descriptors character states used for each descriptor \\
\hline Morphometric descriptors & Measured from the base of the culm to the top of the upper most leaf (cm) \\
\hline Plant height & Number of tillers (n) \\
\hline Tillering abiliity & Total number of leaves (n) \\
\hline Number of leaves & \\
\hline Vegetative descriptors & Days after seeding (DAS) when 50\% of the seedlings emerged. \\
\hline Days to growth stage 2 (emergence) & Ratio between the total seeds planted and the number of seedlings emerged evaluated at 30 DAS. \\
\hline Percentage of total emergence & DAS when 50\% of the plants presented at least 2 tillers. \\
\hline Days to growth stage 3 (tillering) & \\
\hline Reproductive descriptors & DAS when 50\% of the plants presented booting. \\
\hline Days to growth stage 4 (booting) & DAS when the first panicle of a plot reached anthesis. \\
\hline Days to initiate anthesis & DAS when the principal panicle of 50\% of the plants in a plot reached anthesis. \\
\hline Days to 50\% anthesis & Number of days between the beginning and the end of anthesis. \\
\hline Anthesis duration & DAS when harvest was performed and seed had reached physiological maturity. \\
\hline Days to growth stage 9 (maturity)
\end{tabular}


Table 3 - Days after seeding necessary to reach each growth stage in weedy rice morphotypes and commercial rice varieties. Means \pm standard deviations are shown

\begin{tabular}{|c|c|c|c|c|c|c|c|}
\hline Morphotype & $\begin{array}{c}\text { Stage } 2 \\
\text { emergence }\end{array}$ & $\begin{array}{l}\text { Stage } 3 \\
\text { tillering }\end{array}$ & $\begin{array}{l}\text { Stage } 4 \\
\text { booting }\end{array}$ & $\begin{array}{l}\text { Beginning of } \\
\text { anthesis }\end{array}$ & $50 \%$ anthesis & $\begin{array}{c}\text { Stage } 9 \\
\text { maturity }\end{array}$ & $\begin{array}{l}\text { Anthesis } \\
\text { duration }\end{array}$ \\
\hline WM-021 & $7.3 \pm 2.1$ & $20.8 \pm 2.9$ & $78.3 \pm 2.9$ & $82.5 \pm 4.4$ & $87.0 \pm 4.8$ & $113.3 \pm 4.5$ & 21.3 \\
\hline WM-023 & $5.8 \pm 1.8$ & $26.0 \pm 7.9$ & $80.0 \pm 3.1$ & $84.2 \pm 3.9$ & $88.8 \pm 3.3$ & $112.8 \pm 2.7$ & 18.2 \\
\hline WM-123 & $6.5 \pm 0.9$ & $27.8 \pm 7.2$ & $84.1 \pm 5.3$ & $88.0 \pm 5.2$ & $92.6 \pm 4.4$ & $118.0 \pm 2.3$ & 20.6 \\
\hline WM-020 & $6.1 \pm 1.0$ & $23.3 \pm 6.2$ & $81.3 \pm 5.9$ & $85.6 \pm 5.7$ & $92.7 \pm 4.8$ & $118.8 \pm 2.1$ & 24.9 \\
\hline WM-071 & $9.0 \pm 2.2$ & $23.4 \pm 7.4$ & $82.4 \pm 0.9$ & $89.2 \pm 1.1$ & $92.8 \pm 2.2$ & $116.4 \pm 2.9$ & 15.6 \\
\hline WM-121 & $6.4 \pm 1.0$ & $26.4 \pm 5.9$ & $85.1 \pm 2.8$ & $89.3 \pm 3.5$ & $93.1 \pm 3.0$ & $117.0 \pm 2.0$ & 16.0 \\
\hline WM-073 & $8.5 \pm 2.1$ & $24.0 \pm 4.2$ & $83.5 \pm 6.4$ & $88.0 \pm 5.7$ & $93.5 \pm 4.9$ & $118.5 \pm 3.2$ & 23.0 \\
\hline WM-329 & $6.0 \pm 1.1$ & $28.5 \pm 10.7$ & $85.3 \pm 3.0$ & $89.3 \pm 1.0$ & $94.5 \pm 1.2$ & $117.5 \pm 4.2$ & 19.2 \\
\hline WM-171 & $7.5 \pm 0.7$ & $22.5 \pm 2.1$ & $89.0 \pm 1.4$ & $90.0 \pm 0.9$ & $95.0 \pm 1.0$ & $117.0 \pm 2.0$ & 14.5 \\
\hline WM-120 & $6.8 \pm 1.1$ & $22.6 \pm 6.1$ & $83.0 \pm 3.3$ & $91.0 \pm 4.1$ & $95.2 \pm 4.5$ & $120.6 \pm 3.0$ & 21.0 \\
\hline WM-122 & $6.1 \pm 1.1$ & $21.4 \pm 4.3$ & $86.0 \pm 2.6$ & $90.0 \pm 1.6$ & $95.4 \pm 1.8$ & $119.0 \pm 2.6$ & 19.9 \\
\hline WM-070 & $7.0 \pm 2.7$ & $20.2 \pm 7.2$ & $87.8 \pm 5.8$ & $93.8 \pm 4.7$ & $98.0 \pm 4.4$ & $120.4 \pm 3.1$ & 17.0 \\
\hline WM-379 & $11.6 \pm 0.7$ & $17.0 \pm 2.1$ & $88.0 \pm 0.9$ & $95.0 \pm 0.5$ & $99.0 \pm 1.2$ & $122.0 \pm 4.2$ & 19.0 \\
\hline WM-173 & $10.0 \pm 1.0$ & $21.0 \pm 2.9$ & $92.0 \pm 1.4$ & $95.0 \pm 1.0$ & $102.0 \pm 1.4$ & $124.0 \pm 3.0$ & 21.0 \\
\hline WM-024 & $9.4 \pm 1.3$ & $35.8 \pm 7.1$ & $94.6 \pm 2.9$ & $98.4 \pm 2.6$ & $102.2 \pm 2.5$ & $124.8 \pm 2.1$ & 16.6 \\
\hline WM-170 & $12.5 \pm 3.0$ & $22.5 \pm 2.1$ & $94.5 \pm 6.4$ & $98.5 \pm 4.9$ & $102.5 \pm 4.9$ & $125.0 \pm 1.0$ & 15.5 \\
\hline \multicolumn{8}{|c|}{ Early varieties } \\
\hline Setesa-9 & $9.3 \pm 1.0$ & $22.8 \pm 3.8$ & $98.0 \pm 0.7$ & $104.5 \pm 1.7$ & $111.0 \pm 1.2$ & $144.0 \pm 4.3$ & 27.5 \\
\hline CR-5272 & $11.6 \pm 1.5$ & $20.8 \pm 2.9$ & 104. $0 \pm 1.6$ & $103.8 \pm 1.5$ & $114.8 \pm 2.4$ & $145.0 \pm 2.4$ & 29.3 \\
\hline CR-4338 & $11.8 \pm 1.1$ & $21.0 \pm 8.1$ & $103.8 \pm 5.3$ & $108.3 \pm 3.3$ & $115.0 \pm 2.0$ & $147.0 \pm 2.3$ & 25.8 \\
\hline \multicolumn{8}{|l|}{ Late varieties } \\
\hline CR-1821 & $9.4 \pm 0.9$ & $20.8 \pm 8.6$ & $118.0 \pm 2.3$ & $121.5 \pm 1.7$ & $125.0 \pm 2.3$ & $153.8 \pm 2.0$ & 20.3 \\
\hline CR-1113 & $9.2 \pm 1.0$ & $21.0 \pm 6.0$ & $115.5 \pm 2.5$ & $122.0 \pm 2.8$ & $129.0 \pm 2.0$ & $155.0 \pm 0.5$ & 19.0 \\
\hline
\end{tabular}

Tillering (second growth stage evaluated) is a very important trait in competitiveness as sociated with leaf area and biomass production. A profusely tillering plant colonizes space very efficiently and has greater panicle density (Estorninos et al., 2002). Weedy rice and cultivated rice began tillering at about the same time and at the same rate. There was a wide variation in the number of days to begin tillering ( $20.2 \pm 7.2$ to $35.8 \pm 7.1 \mathrm{DAS})$, but no significant differences $(p>0.05)$ were found between weedy and cultivated rice for this trait (Table 3 ). The variation in tillering ability seemed to be wider among weedy rice morphotypes (28.2 - 62.3 tillers at 70 DAS) than among cultivated varieties (33.2 43.4 tillers at 70 DAS) (Figure 2). Nevertheless, the large values of the standard deviation observed in weedy rice morphotypes reflect a wider variability in tillering ability among accessions of the same morphotype (Figure 2). However, this wide range of variation within mor photypes probably prevents statistical differentiation in tillering ability between morphotypes. Additionally, weedy rice morphotypes and commercial rice varieties produced a similar number of leaves during the vegetative phase. At 70 DAS weedy rice had an average of 97 to 164 leaves per plant, whereas the commercial varieties presented 121 to 168 leaves per plant. A positive correlation $(r=0.94-0.99)$ was observed when comparing the number of tillers and number of leaves per plant for both the commercial rice varieties and the weedy morphotypes.

Regarding plant height, all weedy rice morphotypes were significantly taller than commercial rice varieties throughout the vegetative phase (Figure 1). Weedy rice 
morphotypes varied widely in culm height $(68 \pm 4.2-106 \pm 18.6 \mathrm{~cm}$ at $70 \mathrm{DAS})$. Similar results were reported by Noldin et al., (1999) and by the morphological characterization of Costa Rican weedy rice performed by Arrieta-Espinoza et al. (2005). In addition, the standard deviation values indicated also a high variation within morphotypes. In the case of morphotypes WM-120, WM-173 and WM-379 height variations among accession of the same morphotypes were the highest $(92 \pm 23.8,102$ \pm 19.9 and $106 \pm 18.6$, respectively, at 70 DAS), while commercial rice varieties were more uniform $(48 \pm 3.2$ to $65 \pm 9.3 \mathrm{~cm})$, with Setesa-9 being the tallest variety. It is interesting to mention that weedy rice morphotypes increased in height 10 to $30 \mathrm{~cm}$ every two weeks. In contrast, the increase in height for commercial rice varieties was considerably lower $(8$ to $14 \mathrm{~cm}$ ) during the same periods.

A multiple comparison Tukey test for plant height was performed. The five commercial rice varieties were statistically separated $(p \leq 0.05)$ from all the weedy morphotypes (group a). The weedy rice morphotypes were in three overlapping groups b, c and d (Figure 1). Morphotypes WM-024, WM-023, WM-122 and WM-170 (the shortest morphotypes), assigned to groups $\mathrm{b}$ and $\mathrm{c}$, were significantly shorter than WM-020, WM-171, WM-173 and WM379 (the tallest morphotypes) from group $d$. Whereas, morphotypes WM-121, WM-021, WM-123, WM-070, WM-329, WM-073 and WM-120 were included in groups b, c and d indicating that no differences in plant height were found among them (Figure 1). It is interesting to mention that at least one accession in morphotypes WM-024, WM-023, WM-122, WM-120 and WM-173 showed similar or equal height to the commercial varieties. Therefore, field identification of these plants could be difficult during the vegetative stage. In contrast, weedy morphotypes WM-171, WM-173 and WM-379 were about double the height of the commercial rice varieties CR-1113 and CR-5272 at the end of the vegetative phase (70 DAS) (Figure 1). It has

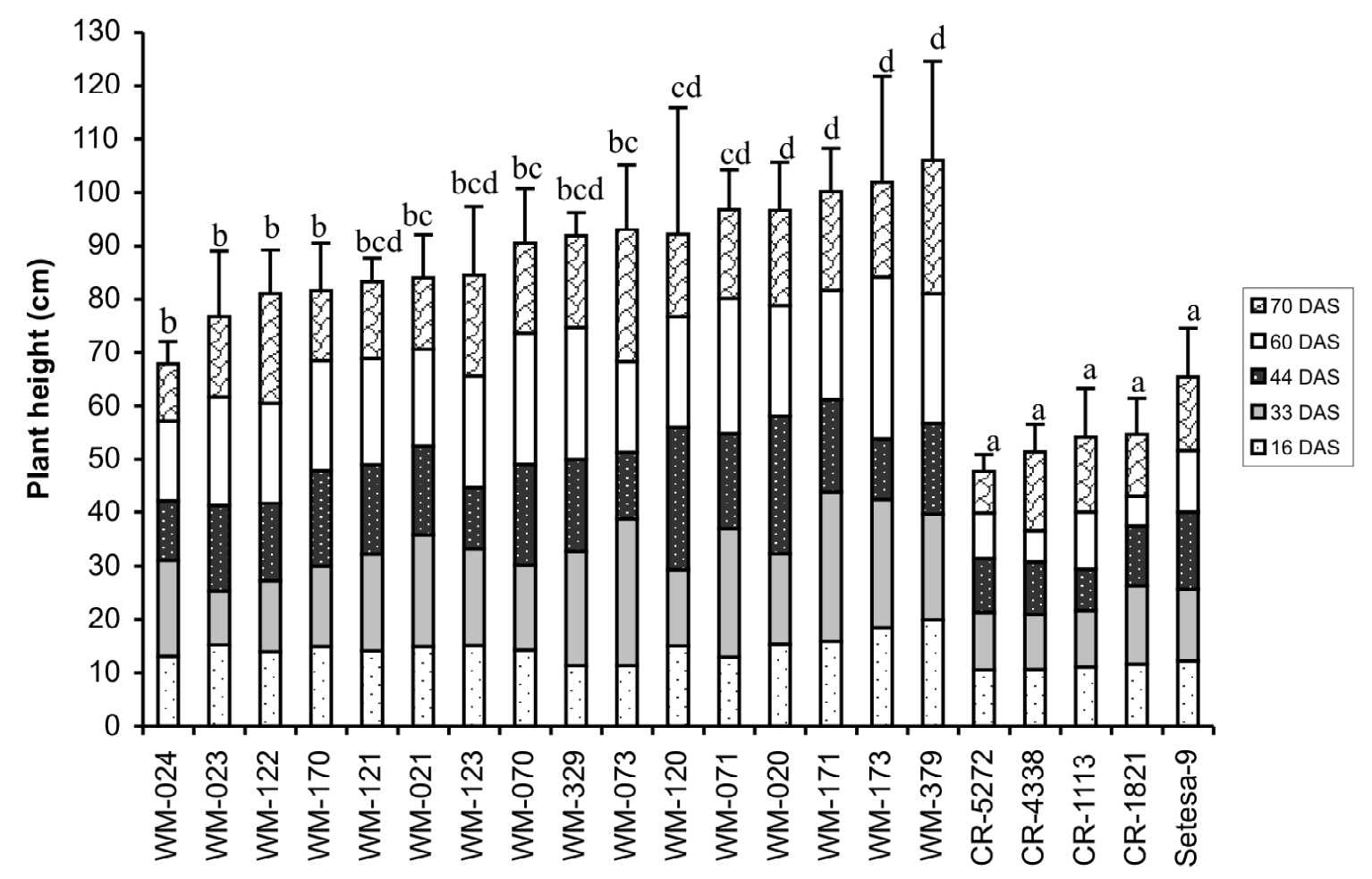

Figure 1 - Cumulative plant height of Costa Rican weedy rice morphotypes and commercial rice varieties at 18, 30, 44, 59, 70 days after seeding (DAS). Bars showed standard deviation at 70 DAS. a, b, c and d are artificial groups obtained by ANOVA multiple mean comparison ( $\mathrm{p}$ d" 0.05 ). 
been demonstrated that taller weedy rice plants compete more efficiently for space and resources in the rice field than commercial varieties (Diarra et al., 1985; Agostinetto et al., 2001). However, these morphotypes were scarce in rice plots (Arrieta-Espinoza et al., 2005), probably due to the fact that easy identification allowed early manual elimination. Additionally, it was observed that taller weedy rice morphotypes showed a tendency to lodge during the reproductive phase.

A negative correlation $(r=0.5)$ between height and number of tillers was observed in weedy morphotypes and commercial rice varieties at 70 DAS. This correlation between height and tillering suggested that in the weedy rice morphotype both characters are not exhibited simultaneously. Therefore, in general terms, for weedy rice, the results suggested that taller plants produced less tillers than shorter plants. It is interesting to point out that the variety CR-1821 did not exhibit this behavior as it showed the highest tiller number and the second highest height (Figure 3).
In summary, early seed emergence, plant height, fast tiller initiation and profuse tillering are important traits associated with weedy rice competitiveness. Based on these traits, the most competitive morphotypes found in this study were WM-021 and WM-070, which combined early emergence with fast and profuse tillering. In contrast, WM-329 and WM-123, with poor and slow tillering, could be less competitive than other weedy rice morphotypes. Among the varieties, the most competitive were CR-1821 and Setesa- 9 because of their early emergence, profuse tillering and plant height. However, considering that the type and number of morphotypes present on each rice farm could differ widely (Arrieta-Espinoza et al., 2005), inventories on the diversity of weedy rice morphotypes and their life cycle should be carried out to plan efficient control strategies for each farm. For instance, if early emergence or taller weedy rice morphotypes were predominantly present in the field, the best strategy for control would be the use of pregerminated seed. However, if profuse tillering morphotypes were present, high rice density would be a better control strategy.

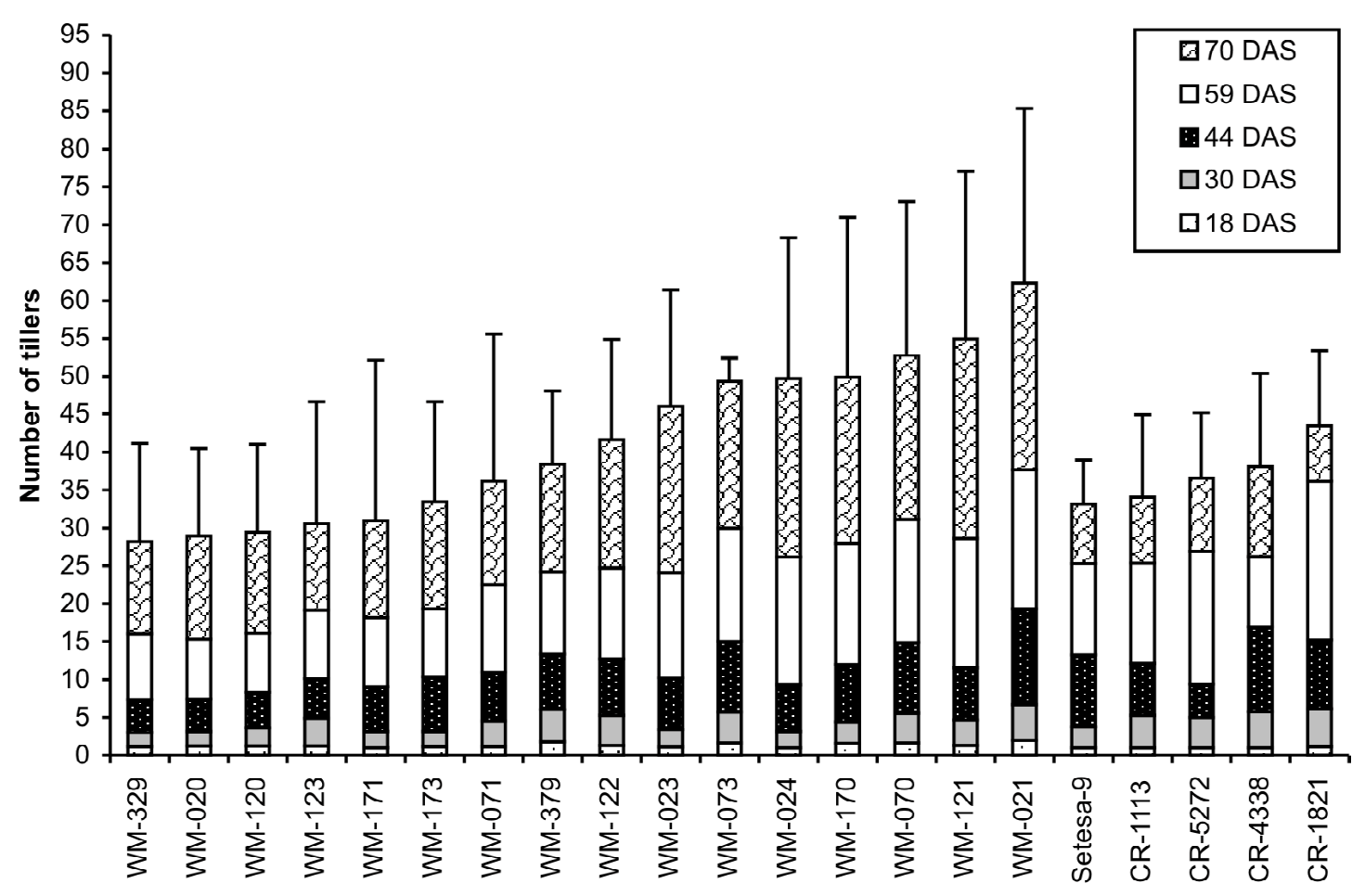

Figure 2 - Cumulative number of tillers per plant produced by Costa Rican weedy rice morphotypes and commercial rice varieties at 18, 30, 44, 59, 70 days after seeding (DAS). Bars showed standard deviation at 70 DAS. 


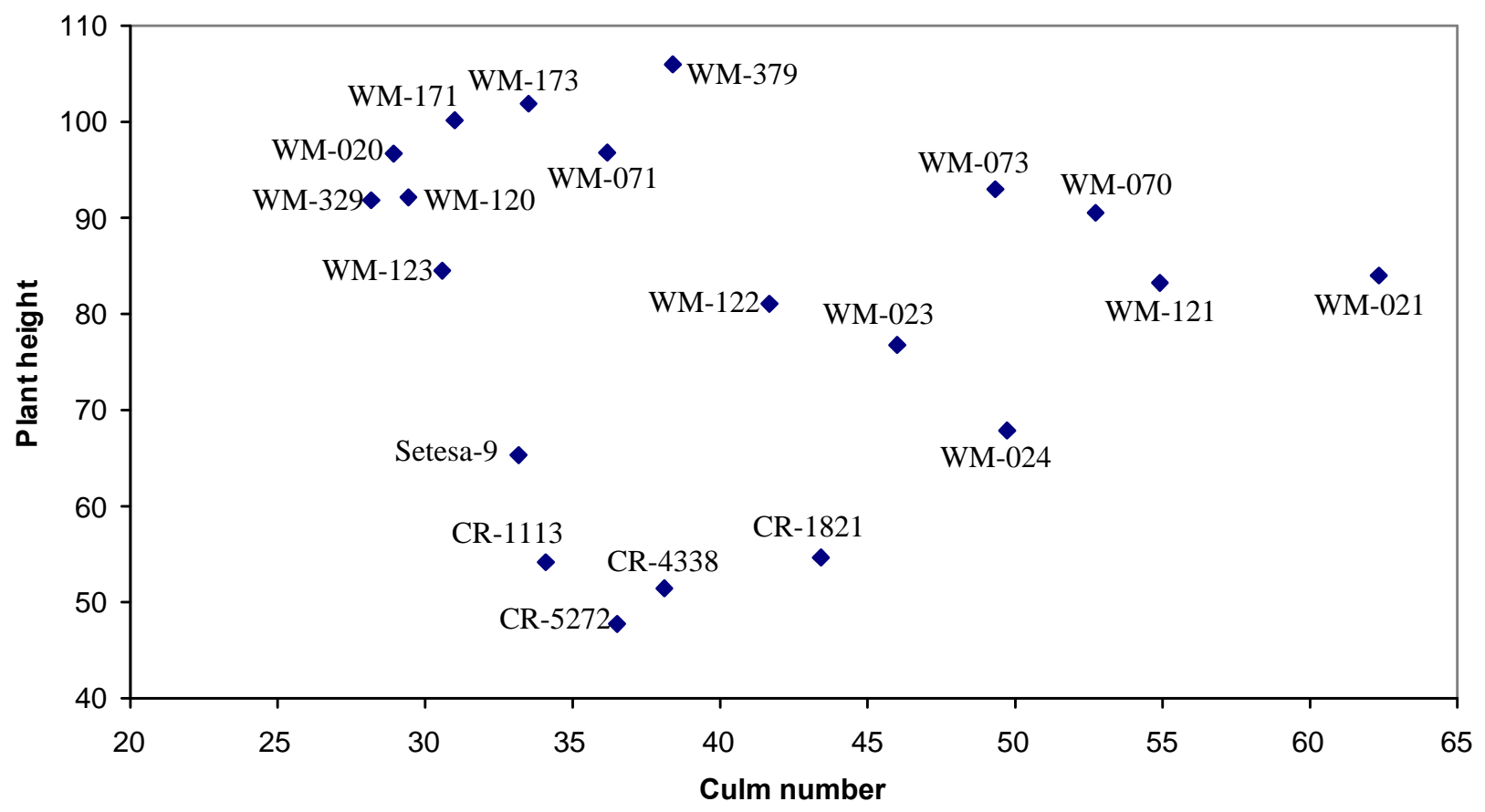

Figure 3 - Relation between culm number and plant height for the weedy rice morphotypes and the commercial rice varieties at 70 DAS.

\section{Reproductive phase}

The life cycle of weedy rice and cultivated rice was divided into vegetative (emergence and tillering) and reproductive phases (booting, anthesis and maturity). Even though some morphotypes emerged earlier than others, this tendency was not linked to early flowering. Thus, no correlation was observed between the vegetative and reproductive phases in any of the sixteen morphotypes $(p=0.691)$. Therefore, it was observed that the morphotypes that first emerged did not reach flowering first, compared to morphotypes with late emergence.

Uneven flowering is a competitive strategy that weedy rice plants use to overcome possible adverse weather conditions during reproductive phase. Accessions from the same weedy rice morphotype were more heterogeneous in the flowering period than commercial varieties. Regarding reproductive phase, weedy rice reached booting between $78.3 \pm 2.9$ and 94.6 $\pm 2.9 \mathrm{DAS}$. In contrast, commercial rice varieties reached this stage later, between 98.0 \pm 0.7 and $118 \pm 2.3$ DAS. The time elapsed between booting and 50\% anthesis varied from 6.0 to 13.5 days both for weedy rice morphotypes and cultivated varieties (Table 3 ). All weedy rice morphotypes reached 50\% anthesis between $87.0 \pm 4.8$ to $102.5 \pm 4.9 \mathrm{DAS}$. Statistical differences between morphotypes in anthesis period were only observed between the earliest and latest flowering morphotypes, while intermediate flowering morphotypes could not be distinguished from the early and late ones. In this sense, morphotypes WM-021 and WM-023 showed earlier anthesis than the late flowering morphotypes WM-122, WM-070, WM-379, WM-173, WM024 and WM-170. In contrast, WM-024 reached anthesis significantly later than the early mor photypes WM-021, WM-023, WM-123, WM-020, WM-071 and WM-121. Three groups were established by comparison of means for days to reach anthesis. One group was composed by the sixteen weedy rice morphotypes, while the other two groups contained the commercial rice varieties. All weedy rice bloomed earlier than commercial rice varieties. Furthermore, high standard deviations recorded for $50 \%$ anthesis reflected a more heterogeneous flowering with in morphotypes than within varieties. The 
commercial rice varieties formed two discrete groups: one "early flowering" group (reaching $50 \%$ of anthesis between $111.0 \pm 1.2$ and $115.0 \pm 2.0$ DAS) composed of CR-5272, CR-4338 and Setesa-9 varieties and a second "late flowering" group (reaching $50 \%$ of anthesis between $125.0 \pm 2.3$ and $129.0 \pm 2.0$ DAS) including CR-1113 and CR1821 (Table 3). The varieties CR-1113 and CR-1821 had the shortest anthesis span (19-20 days), whereas Setesa- 9 and CR-4338 showed 26 and 27 days respectively. Finally, CR-5272 presented the longest anthesis interval (29 days). The weedy morphotypes WM-071, WM-121, WM-17 1, WM-024, WM-070 WM-170 and WM-023 presented anthesis intervals of 14.5 to 18.5 days, while the morphotypes WM-123, WM-329, WM-379, WM-173, WM-021 WM-122 and WM-120 showed anthesis spans of 19 to 22 days. Among morphotypes, the longest intervals were observed for WM-020 and WM-073 (23 to 25 days) (Table 3). The weedy rice morphotypes reached maturity in a narrow window (13.2 days) (Table 3 ). Weedy rice matured earlier $(112.8 \pm 2.7$ to $125.0 \pm$ 1.0 DAS) than commercial varieties $(144.0 \pm$ 4.3 to $155.0 \pm 0.5 \mathrm{DAS})(\mathrm{P} \leq 0.001)$. Within commercial rice varieties, CR-5272, CR-4338 and Setesa-9 reached maturity at $144.0 \pm$ 4.3 to $147.0 \pm 2.3$ days, whereas CR-1113 and CR-182 1 required $153.8 \pm 2.0-155.0 \pm 0.5$ days to mature. The uneven flowering and maturation observed in this study suggest that these traits guarantee a better performance of the progeny in the field, and ensure reproductive fitness not for a particular individual of weedy rice but for the complex as a whole. The diversity in flowering period assures continuous production and maturation of seeds from different morphotypes (Ferrero, 2003).

This study also provides important information on flowering overlapping among the weedy rice morphotypes found in Parrita and five commercial rice varieties used in Costa Rica. Anthesis overlap is the first requirement for hybridization as it is a prerequisite for

\section{Days between weed / crop flowering}

Duration of overlapping flowering

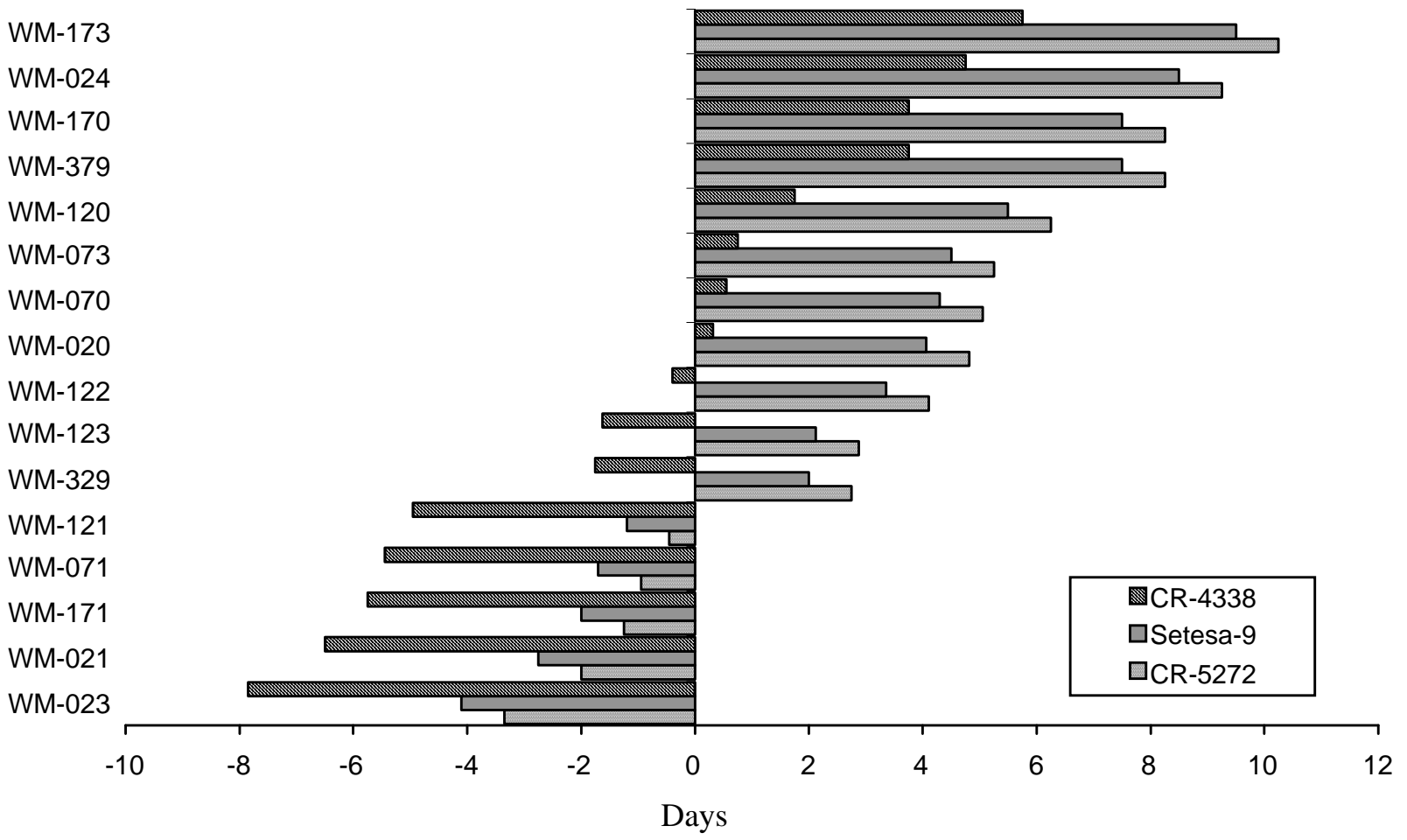

Figure 4 - Anthesis overlapping of the commercial rice varieties (CR-5272, CR-43338 y Setesa-9) and weedy rice morphotypes. Positive numbers indicate the overlapping spans in days; negative numbers indicate the days elapsed from the end of anthesis in weedy rice and initiation of anthesis in the commercial rice varieties. 
cross-pollination (Langevin et al., 1990). In this sense, the three "early flowering" weedy rice morphotypes WM-021, WM-023 and WM-171 did not overlap anthesis with any of the commercial varieties. CR-5272 and Setesa-9 overlapped flowering with eleven morphotypes, while CR-4338 overlapped anthesis with eight weedy rice morphotypes (Figure 4). The mor photypes WM-020, WM-070, WM-073, WM-120, WM-379, WM-170, WM-024 and WM173 overlapped anthesis to some extent with the varieties CR-4338, Setesa-9 and CR-5272. Conversely, the late flowering varieties CR-1821 and CR-1113 did not overlap with any morphotype. Therefore, regarding gene flow potential, the eleven weedy rice morphotypes that overlap flowering with the commercial varieties CR-5272 and Setesa-9 are putative candidates for hybridization with weedy rice. On the other hand, the varieties CR-1113 and CR-1821 did not overlap anthesis with any weedy rice morphotype, reducing the possibility for gene flow under natural field conditions.

Finally, the simultaneous study of the growth stages of the weedy rice morphotypes and commercial rice varieties provided information for planning biosafety experiments that involve herbicide resistance rice. The results will allow the selection of a representative sample from the weedy rice complex, considering the differences in anthesis overlap between weedy rice and commercial rice varieties, to perform gene flow studies under tropical conditions.

\section{ACKNOWLEDGMENTS}

The authors wish to thank Sergio Vargas for his assistance in statistical analyses and Dr. B. Valverde for valuable comments to the manuscript. This work was carried out in collaboration with the "Gene flow analysis for assessing the safety of bio-engineered crops in the tropics" Project No. 997860200100 convened by CIAT, Cali, Colombia and financed by BMZ and GTZ, Germany. Also this research has been supported by funds from CONICIT and the Rockefeller Foundation.

\section{LITERATURE CITED}

AGOSTINETTO, D. et al. Arroz vermelho: Ecofisiologia e estratégias de controle. Ci. Rural, v. 31, p. 341-349, 2001.
AGOSTINETTO, D. et al. Grain yield losses in flooded rice crop as a function of plant population and relative emergence timing of red rice or their genotype simulator. Planta

Daninha, v. 22, p. 175-183, 2004.

AGÜERO, R. Malezas del arroz y su manejo. San José, Costa Rica: I.M.R, 1996.

ARRIETA-ESPINOZA, G. et al. The weedy rice complex in Costa Rica. I morphological study and relationship between commercial rice varieties and wild Oryza relatives and weedy types. Genet. Res. Crop Evolution, v. 52, p. 575-587, 2005.

COHN, M. A. et al. Seed dormancy in red rice. Plant Physiol., v. 84, p. 716-719, 1987.

COHN, M. A. et al. Seed dormancy in red rice. Plant Physiol., v. 89, p. 879-882, 1989.

DELATORRE, C. A. Dormência em sementes de arroz vermelho. Ci. Rural, v. 29, p. 565-571, 1999.

DIARRA, A.; SMITH, R. J.; TALVERT, R. Growth and morphological characteristics of red rice (Oryza sativa L.) biotypes. Weed Sci., v. 33, p. 310-314, 1985.

ESQUEDA, V. A. Control químico del arroz rojo (Oryza sativa L.) en arroz, con herbicidas no selectivos protectantes a la semilla. Agron. Mesoam., v. 11, p. 57-61, 2000.

ESTORNINOS, L. E.; GEALY, D. R.; TALBERT, R. E. Growth response of rice (Oryza sativa) and red rice (Oryza sativa) in a replacement series study. Weed Technol., v. 16, p. 401-406, 2002.

FERRERO, A. Weedy rice, biological features and control. Roma: FAO, 2003. p. 89-107. (FAO Plant Production and Protection Paper, 120 Add.1)

FONSECA, J. R. et al. Morphological, agronomic and phenologic descriptors of rice land races collected in Maranhão-Brazil. R. Ceres, v. 51, p. 45-56, 2004.

GEALY, D. R.; SANDAIN, N. E.; TALBERT, R. E. Emergence of red rice (Oryza sativa) ecotypes under dryseeded rice (Oryza sativa) culture. Weed Technol., v. 14, p. 406-412, 2000.

HERNÁNDEZ, L.; ARMENTA, J. L.; NIEVES, T. Arroz rojo, amenaza de las variedades comerciales en Mexico. Culiacán, Mexico: Instituto Nacional de Investigaciones Agrícolas. Centro de Investigaciones Agrícolas de Sinaloa (CIAS), 1979. 37p.

INTERNATIONAL RICE RESEARCH INSTITUTE - IRRI Standard evaluation system for rice. Manila: International Rice Research Institute, Rice Knowledge Bank. 2002. Available at: www.knowledgebank.irri.org/ses/SES.htm. 
KWON, S. L.; SMITH, R. J.; TALBERT, R. E. Interference durations of red rice (Oryza sativa) in rice (Oryza sativa). Weed Sci., v. 39, p. 363-368, 1991.

LANGEVIN, S. A.; CLAY, K.; GRACE, J. B. The incidence and effects of hybridization between cultivated rice and its related weed red rice (Oryza sativa L.). Evolution, v. 44, p. 1000-1008, 1990.

MADSEN, K. H.; VALVERDE, B. E.; JENSEN, J. E. Risk assessment of herbicide-resistant crops: A Latin American perspective using rice (Oryza sativa) as a model. Weed Technol., v. 16, p. 215-223, 2002.

MONTEALEGRE, F. A.; VARGAS, J. P. Manejo y caracterización del arroz rojo en Colombia. In: CONFERÊNCIA INTERNACIONAL DE ARROZ PARA AMÉRICA LATINA Y CARIBE, 8., 1992, Cali. Memorias... Cali: CIAT, 1992. p. 125-168.
NOLDIN, J. A.; CHANDLER, J. M.; McCAULEY, G. N. Red rice (Oryza sativa) biology. I Characterization of red rice ecotypes. Weed Tecnol., v. 13, p. 12-18, 1999.

O`DONOVAN, J. T. et al. Influence of the relative time of emergence of wild oat (Avena fatua) on yield loss of barley (Hordeum vulgare) and wheat (Triticum aestivum). Weed Sci., v. 33, p. 498-503, 1985.

OFICINA NACIONAL DE SEMILLAS - ONS. Memorias Oficina Nacional de Semillas. San José, Costa Rica: 1997/ 2005.

ORTIZ, A.; LOPEZ, M.; LIZASO, J. Desarrollo y caracterización morfológica de ecotipos de arroz rojo y cultivares de arroz en Venezuela. Agron. Trop., v. 49, p. 51-67, 1999.

PANTONE, D. J.; BAKER, J. B. Reciprocal yield analysis of red rice (Oryza sativa) competition in cultivated rice. Weed Sci., v. 39, p. 42-47, 1991. 